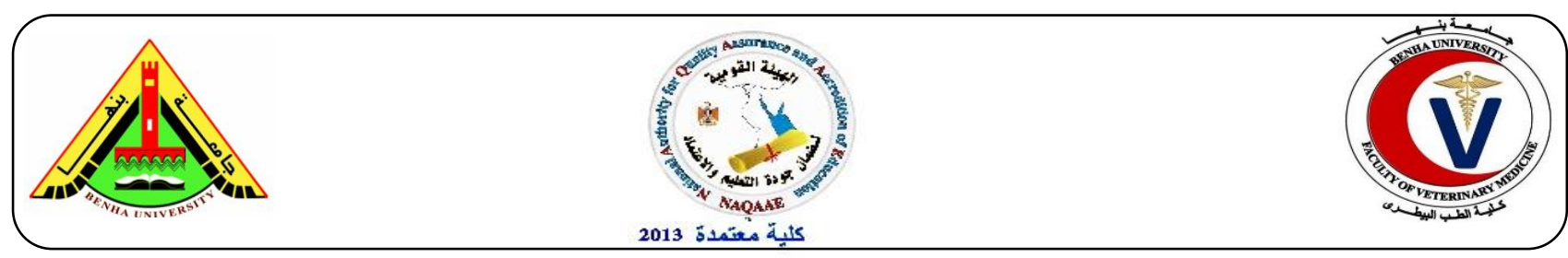

\title{
Neurodegeneration and oxidative stress induced by tramadol administration in male rats: The effect of its withdrawal
}

\author{
Samy Ali Hussein ${ }^{1 *}$; Samir Abdel Latif Abdel Aal'and Hany k. Ismail ${ }^{1}$ \\ ${ }^{1}$ Department of Biochemistry, Faculty of Vet. Med., Benha University, Egypt \\ ${ }^{2}$ Department of Animal, Poultry and Environmental Hygiene, Faculty of Vet. Med. , Benha University, Egypt. \\ *Corresponding author: Samy Ali Hussein; email: samyaziza@yahoo.com
}

\begin{abstract}
A B S T R A C T
The purpose of this study was to evaluate the possible neurodegeneration and oxidative stress induced by tramadol administration in male rats. One hundred male albino rats were divided into three groups. Group I (normal control): consisted of twenty rats, administered saline solution. Group II (therapeutic dose gp): forty rats, received oral dose of tramadol $\mathrm{HCl}$ suspended in saline solution equivalent to $22.5 \mathrm{mg} / \mathrm{kg} /$ day for nine weeks; ten rats were left for further two weeks without any additional treatment as a recovery period. Group III (over- dose gp): forty rats, received oral dose of tramadol $\mathrm{HCl}$ suspended in saline solution at doses of 30 , 60 and $90 \mathrm{mg} / \mathrm{kg} /$ day on the first, the second and the third three weeks of the study, respectively; ten rats were left from Group III for further two weeks without any additional treatment as a recovery period. The obtained results showed significant increase in serum liver marker enzyme (ALT and AST) activities, and brain tissue MDA, NO, DNA fragmentation, 8-OHdG and caspase-3 in both tramadol therapeutic and overdose groups. However, brain tissue antioxidant enzyme (SOD and CAT) activities were markedly decreased. Tramadol withdrawal for two weeks produced significant improvement of all previous parameters towards its normal ranges. These results proved that, tramadol administration for 9 weeks induced liver dysfunction and brain injury in rats, as well as a degenerating endogenous antioxidant defense system mechanism. These findings are of importance to be considered in patients who use tramadol as a pain killer, especially in the long term conditions.
\end{abstract}

Keywords: Neurotoxicity, Oxidative stress, Tramadol.

(http://www.bvmj.bu.edu.eg)

(BVMJ-33(2): 149-159, DECEMBER,2017

\section{INTRODUCTION}

Drugs are natural or synthetic substances used for medical purposes. However, the irrational use of some of these drugs may lead to transient or chronic dependency (Murthy et al., 2010). Drug abuse has become a major social problem of the modern world as it is very common and involves lifetime exposure of about $46 \%$ of the general population (Pantelias and Grapsa, 2011). Addiction is a chronic disease characterized by compulsive drug seeking and uses (NIDA, 2014). Drug abuse cause and contribute to the deaths of millions of people every year by worsening comorbid psychiatric symptoms, such as depression, and physical illness, such as cirrhosis of the liver, while also aiding in the spread of infectious diseases such as human immunodeficiency virus (HIV), hepatitis B and hepatitis C. Drug abuse is also linked to crime and disability (UNODC, 2014).

The abuse liability of naturally occurring opiates (e.g., morphine, codeine) and synthetic opioids (e.g.Tramadol, heroin, oxycodone, and buprenorphine) is well known (Moratti et al., (2010); Meyer et al., (2014)). Tramadol is an analgesic that was manufactured in Germany more than 35 years ago. It is centrally acting analgesic with weak opioid action. It also possesses catecholamine and serotonin (5-HT) reuptake inhibitory property (Liu and Liu, 2013). Long- term administration of tramadol for management of pain, as well as its use as an 
acceptable alternative in persons with drugseeking behavior is controversial (Drugs and Therapy Bulletin, 2002). Also, long- term effects of tramadol at cellular level, are not clearly understood (Atici et al., 2005). Tramadol exerts its analgesic effect through at least two complementary and synergistic mechanisms; the first is by activating the $\mu$-opioid receptor (Ide et al., 2006), and the second is by inhibition of the neuronal uptake of noradrenaline and serotonin (Raffa et al., 1992).

The liver and kidney are responsible for tramadol metabolism and excretion. Therefore, may cause hepatotoxicity and nephrotoxicity during its metabolism (Wu et al., (2001); Atici et al., (2005)).

Oxidative stress is a phenomenon which is related to the development of many pathological conditions. Pathologies where reactive oxidative species (ROS) were identified as causal factors include cardiovascular disease, diabetes, rheumatoid arthritis, cancer, and neurodegenerative disorders (Valko et al., 2007). The main reported adverse drug reactions for tramadol are nausea, vomiting, sweating, itching, constipation, headache, and central nervous system stimulation. Most of these reactions are dose dependent.

Neurotoxicity of tramadol has been reported in patients receiving tramadol both at the recommended dosage and at the high dosage ranges in human studies (Bekjarovski et al., 2012). The neurotoxicity of tramadol commonly manifests as generalized tonic-clonic seizures. Chronic use of tramadol in increasing doses causes neuronal degeneration in the rat brain, which probably contributes to cerebral dysfunction (Atici et al., 2005). Tramadol also alters brain neurotransmitter levels (Bloms-Funke et al., 2011). Therefore, this study was designed to investigate the possible deleterious effects of tramadol administration in adult male rats through determination of hepatic functions, and oxidative stress biomarkers, DNA damage and antioxidant enzymatic status.

\section{MATERIALS AND METHODS}

\subsection{Experimental animals:}

One hundred male albino rats of weighing $180-$ $200 \mathrm{~g}$ were used as a parallel study design. Rats were housed in separated metal cages and kept at constant environmental condition of temperature $\left(22 \pm 1^{\circ} \mathrm{C}\right)$ and humidity throughout the period of experiment. The rats were fed on constant diet and fresh, clean drinking water was supplied $a d$ - libitum. All rats were acclimatized for a period of two weeks prior to the beginning of the study.

\subsection{Drug:}

Tramadol $\mathrm{HCl}$ was obtained as $\mathrm{Tamol}^{\circledR}, 225 \mathrm{mg}$ tablets, which was obtained from Alkan- Pharm ${ }^{\circledR}$, Egypt.

\subsection{Experimental design:}

After acclimatization to the laboratory conditions, the animals were randomly divided into three groups placed in individual cages and classified as follows:

Group I (Control normal group): Twenty normal non-medicated rats served as control for all experimental groups, and received $1 \mathrm{ml}(0.9 \%$ $\mathrm{NaCl}$ ) oral doses of saline solution for nine weeks.

Group II (Therapeutic dose group): forty rats in group II received a daily oral dose of tramadol $\mathrm{HCl}$ suspended in saline solution equivalent to $22.5 \mathrm{mg} / \mathrm{kg} /$ day for nine weeks. Ten rats were left for further two weeks without any additional treatment as a recovery period.

Group III (Over dose group): forty rats in group III received oral dose of tramadol $\mathrm{HCl}$ suspended in saline solution at doses of 30,60 and 90 $\mathrm{mg} / \mathrm{kg} /$ day on the first, the second and the third three weeks of the study, respectively. Ten rats were left for further two weeks without any additional treatment as a recovery period.

\subsection{Sampling:}

\subsubsection{Blood samples:}

About $2 \mathrm{ml}$ of blood samples were collected by retro orbital venous plexus puncture at the medial canthus from all animals after nine and eleven weeks (as recovery period) from the onset of the experiment. Blood samples were collected in dry, clean tubes and allowed to clot for 30 minutes and sera were separated by centrifugation at 3000 r.p.m for 15 minutes. The serum was taken by automatic pipette and received in dry clean tubes, then kept in deep freezer at $-20^{\circ} \mathrm{C}$ until use for subsequent biochemical analysis. All sera were analysed for determination of the following parameters: alanine transaminase (ALT) and aspartate transaminase (AST).

2.4.2. Tissue samples (brain and liver):

About $0.5 \mathrm{~g}$ of brain tissue specimens were taken two times after scarifying rats at nine and eleven weeks from the onset of the experiment. The 
specimens were immediately removed and washed several times with saline and blotted between two damp filter papers, weighed and stored at $-20^{\circ} \mathrm{C}$ for subsequent biochemical analyses.

Preparation of brain tissue homogenate:

Briefly, brain tissues were cut, weighed and minced into small pieces, and one gram was homogenized with a glass homogenizer in $9 \mathrm{ml}$ of ice-cold $0.05 \mathrm{mM}$ potassium phosphate buffer $(\mathrm{pH}$ 7.4) to make $10 \%$ homogenates. The homogenates were centrifuged at 6000 r.p.m for 15 minutes at $4^{\circ} \mathrm{C}$ then the resultant supernatant was used for the determination of the following parameters: malondialdehyde (MDA), nitric oxide (NO), superoxide dismutase (SOD), catalase (CAT), DNA fragmentation, 8-hydroxy deoxy-2-guanosine (8-oHdG) and caspase-3.

\subsection{Biochemical analysis}

Serum ALT and AST were determined according to the method described by Schumann et al., (2002). Moreover, brain tissue MDA, NO, CAT, SOD, DNA fragmentation, 8-oHdG and caspase-3 were determined according to the method described by Mesbah et al., (2004), Vodovotz (1996), Luck (1974), Kakkar et al., (1984), Shi et al., (1996), 8-oHdG-StressMarq Biosciences Inc.'s StressXpress ${ }^{\circledR}$ EIA Kits (Cat\# SKT-120-96 (96 well kit) and Rat (Casp-3) ELISA Kit (CUSABIO BIOTECH CO., LTD) Cat.No.CSB-E08857r), respectively.

\subsection{Statistical analysis:}

The results were expressed as mean $\pm \mathrm{SE}$ and statistical significance was evaluated by oneway ANOVA using (SPSS IBM 1983, version10. New York, NY, USA : IBM Incorporation )program followed by the post hoc test, least significant difference (LSD). Values were considered statistically significant when $P<0.05$.

\section{Results:}

The obtained results (demonstrated in Table 1) exhibited that after 9 weeks exposure, there was a significant increase in serum ALT and AST activities accompanied with significant increase in brain tissue MDA, NO concentrations in both tramadol therapeutic and overdose groups when compared with normal control group; while there was a non-significant increase in AST activity in the therapeutic dose group when compared with the normal control group. On the other hand, there was a significant decrease in brain tissue SOD and CAT activities in both tramadol therapeutic and overdose groups when compared with normal control group.

After 2 weeks, without any additional treatment as a recovery period there was a nonsignificant decrease in serum ALT and AST activities accompanied with non-significant decrease in brain tissue MDA, NO concentrations in both tramadol withdrawal therapeutic dose and tramadol withdrawal overdose groups, when compared with therapeutic dose and overdose groups respectively, while there was a significant decrease in serum ALT and brain tissue MDA in tramadol withdrawal therapeutic group when compared with therapeutic group. However, a significant increase in brain tissue SOD and CAT in both tramadol withdrawal therapeutic dose and tramadol withdrawal overdose groups when compared with therapeutic dose and overdose groups, respectively; while there was a nonsignificant increase in brain tissue SOD in tramadol withdrawal over dose group when compared with over dose group.

The obtained results (demonstrated in Table 2) exhibited that after 9 weeks exposure there was a significant increase in brain tissue DNA-fragmentation, OHdG and caspase-3 in both tramadol therapeutic and overdose groups when compared with normal control group; while there was a non-significant increase in DNAfragmentation and caspase-3 levels in the therapeutic dose group when compared with the normal control group.

After 2 weeks, without any additional treatment as a recovery period, there was a nonsignificant decrease in brain tissue DNAfragmentation and caspase-3 activity in both tramadol withdrawal therapeutic dose and tramadol withdrawal overdose groups when compared with therapeutic dose and overdose groups, respectively; while there was a significant decrease in brain tissue $\mathrm{OHdG}$ in both tramadol withdrawal therapeutic and tramadol withdrawal over dose group when compared with therapeutic and over dose group, respectively. 
Table (1) Effect of Tramadol administration at both the recommended dosage and the high dosage ranges on serum ALT, AST and brain tissue MDA, NO, SOD and CAT in rats.

\begin{tabular}{|c|c|c|c|c|c|c|c|c|c|c|c|c|}
\hline \multirow[b]{2}{*}{$\begin{array}{l}\text { Animal } \\
\text { Groups }\end{array}$} & \multicolumn{2}{|c|}{$\begin{array}{l}\text { ALT } \\
(\mathrm{U} / \mathrm{L})\end{array}$} & \multicolumn{2}{|c|}{$\begin{array}{l}\mathrm{AST} \\
(\mathrm{U} / \mathrm{L})\end{array}$} & \multicolumn{2}{|c|}{$\begin{array}{c}\text { MDA } \\
\text { (mmol/g.tissue) }\end{array}$} & \multicolumn{2}{|c|}{$\begin{array}{c}\mathrm{NO} \\
(\mathrm{mmol} / \mathrm{g} . t \mathrm{tit})\end{array}$} & \multicolumn{2}{|c|}{$\begin{array}{c}\text { SOD } \\
(\mathrm{u} / \mathrm{g} . \text { tissu })\end{array}$} & \multicolumn{2}{|c|}{$\begin{array}{c}\text { CAT } \\
\text { (mmol/g.tissue) }\end{array}$} \\
\hline & $\begin{array}{l}9 \text { weeks } \\
\text { treatment }\end{array}$ & $\begin{array}{c}2 \text { weeks } \\
\text { withdrawal }\end{array}$ & $\begin{array}{l}9 \text { weeks } \\
\text { treatment }\end{array}$ & $\begin{array}{c}2 \text { weeks } \\
\text { withdrawal }\end{array}$ & $\begin{array}{l}9 \text { weeks } \\
\text { treatment }\end{array}$ & $\begin{array}{c}2 \text { weeks } \\
\text { withdrawal }\end{array}$ & $\begin{array}{c}9 \text { weeks } \\
\text { Treatment }\end{array}$ & $\begin{array}{c}2 \text { weeks } \\
\text { withdrawal }\end{array}$ & $\begin{array}{l}9 \text { weeks } \\
\text { treatment }\end{array}$ & $\begin{array}{c}2 \text { weeks } \\
\text { Withdrawal }\end{array}$ & $\begin{array}{l}9 \text { weeks } \\
\text { treatment }\end{array}$ & $\begin{array}{c}2 \text { weeks } \\
\text { withdrawal }\end{array}$ \\
\hline $\begin{array}{c}\text { Group I: } \\
\text { (Normal control } \\
\text { group) }\end{array}$ & $25.33 \pm 2.03^{c}$ & $25.33 \pm 2.03^{\mathrm{c}}$ & $33.13 \pm 1.62^{c}$ & $33.13 \pm 1.62^{\mathrm{c}}$ & $4.16 \pm 0.33^{c}$ & $4.16 \pm 0.33^{\mathrm{c}}$ & $39.94 \pm 6.43^{c}$ & $39.94 \pm 6.43^{\mathrm{c}}$ & $69.15 \pm 5.77^{\mathrm{a}}$ & $69.15 \pm 5.77^{\mathrm{a}}$ & $1.63 \pm 0.25^{\mathrm{a}}$ & $1.63 \pm 0.25^{\mathrm{a}}$ \\
\hline $\begin{array}{l}\text { Group: } \Pi \\
\text { (therapeutic } \\
\text { dose group) }\end{array}$ & $37.63 \pm 0.33^{\mathrm{a}}$ & $31.07 \pm 0.17^{\mathrm{b}}$ & $41.67 \pm 2.19^{\mathrm{a}}$ & $37.17 \pm 0.15^{\mathrm{bc}}$ & $7.30 \pm 0.33^{\mathrm{a}}$ & $5.63 \pm 0.14^{\mathrm{b}}$ & $64.48 \pm 4.6^{\mathrm{b}}$ & $54.84 \pm 7.04^{\mathrm{b}, \mathrm{c}}$ & $40.47 \pm 2.28^{\mathrm{d}}$ & $53.17 \pm 2.51^{\mathrm{b}, \mathrm{c}}$ & $0.55 \pm 0.03^{\mathrm{c}}$ & $0.68 \pm 0.02^{\mathrm{c}}$ \\
\hline $\begin{array}{l}\text { Group III: } \\
\text { (over dose } \\
\text { group) }\end{array}$ & $31.48 \pm 1.43^{\mathrm{b}}$ & $28.17 \pm 1.30^{\mathrm{bc}}$ & $38.33 \pm 0.88^{\mathrm{ab}}$ & $35.58 \pm 0.31^{\mathrm{bc}}$ & $5.21 \pm 0.36^{\mathrm{b}}$ & $4.88 \pm 0.27^{\mathrm{bc}}$ & $94.99 \pm 9.55^{\mathrm{a}}$ & $76.4 \pm 7.29^{\mathrm{a}, \mathrm{b}}$ & $51.04 \pm 1.98^{\mathrm{c}}$ & $62.95 \pm 1.35^{\mathrm{a}, \mathrm{b}}$ & $0.66 \pm 0.02^{\mathrm{c}}$ & $1.15 \pm 0.02^{\mathrm{b}}$ \\
\hline
\end{tabular}

Data are presented as (Mean \pm S.E). $\quad$ S.E $=$ Standard error.

Mean values with different superscript letters in the same column are significantly different at $(\mathrm{P} \leq 0.05)$. 
Table (2) Effect of Tramadol administration at both the recommended dosage and the high dosage ranges on brain tissue DNA fragmentation, 8-Ohdg and caspase 3 in rats.

\begin{tabular}{|c|c|c|c|c|c|c|}
\hline \multirow[b]{2}{*}{$\begin{array}{l}\text { Animal } \\
\text { Groups }\end{array}$} & \multicolumn{2}{|c|}{$\begin{array}{l}\text { DNA fragmentation } \\
\text { (cell/g.tit) }\end{array}$} & \multicolumn{2}{|c|}{$\begin{array}{l}\text { 8-Ohdg } \\
\text { (ng/g.tit) }\end{array}$} & \multicolumn{2}{|c|}{$\begin{array}{l}\text { caspase } 3 \\
\text { (ng/g.tit) }\end{array}$} \\
\hline & $\begin{array}{l}9 \text { weeks } \\
\text { treatment }\end{array}$ & $\begin{array}{c}2 \text { weeks } \\
\text { Withdrawal }\end{array}$ & $\begin{array}{l}9 \text { weeks } \\
\text { treatment }\end{array}$ & $\begin{array}{c}2 \text { weeks } \\
\text { withdrawal }\end{array}$ & $\begin{array}{l}9 \text { weeks } \\
\text { treatment }\end{array}$ & $\begin{array}{c}2 \text { weeks } \\
\text { withdrawal }\end{array}$ \\
\hline $\begin{array}{l}\text { Group I: } \\
\text { (Normal control } \\
\text { group) }\end{array}$ & $288.97 \pm 11.22^{\mathrm{a}}$ & $288.97 \pm 11.22^{\mathrm{a}}$ & $1.54 \pm 0.1^{\mathrm{d}}$ & $1.54 \pm 0.1^{\mathrm{d}}$ & $0.88 \pm 0.16^{\mathrm{c}}$ & $0.88 \pm 0.16^{\mathrm{c}}$ \\
\hline $\begin{array}{l}\text { Group: } \Pi \\
\text { (therapeutic dose } \\
\text { group) }\end{array}$ & $461.87 \pm 96.87^{a b}$ & $307.22 \pm 50.38^{\mathrm{c}}$ & $2.46 \pm 0.04^{\mathrm{c}}$ & $1.89 \pm 0.18^{\mathrm{d}}$ & $1.18 \pm 0.07^{\mathrm{b}, \mathrm{c}}$ & $1.04 \pm 0.07^{\mathrm{c}}$ \\
\hline $\begin{array}{l}\text { Group III: } \\
\text { (over dose group) }\end{array}$ & $629.83 \pm 58.79^{\mathrm{a}}$ & $467.34 \pm 63.22^{\mathrm{a}, \mathrm{b}}$ & $3.8 \pm 0.21^{\mathrm{a}}$ & $3.04 \pm 0.04^{\mathrm{b}}$ & $1.91 \pm 0.13^{\mathrm{a}}$ & $1.42 \pm 0.11^{\mathrm{b}}$ \\
\hline
\end{tabular}

Data are presented as (Mean \pm S.E). $\quad$ S.E $=$ Standard error.

Mean values with different superscript letters in the same column are significantly different at $(\mathrm{P} \leq 0.05)$. 


\section{DISCUSSION}

The obtained results showed that after 9 weeks of tramadol exposure there was a significant increase in serum ALT and AST in both tramadol therapeutic and overdose groups when compared with normal control group; while there was a non-significant increase in AST activity in the therapeutic dose group when compared with the normal control group. These results came in accordance with the recorded data of Elwy and Tab, (2014) who revealed that tramadol induced significant increase in serum ALT and AST activities as compared to control rats. Moreover, Hafez et al., (2015) suggested that serum AST and ALT activities increased significantly in tramadol exposed rats indicating toxicity induced by tramadol administration. Similarly, Nna et al., (2015) reported that, after 8 weeks of tramadol administration, serum AST and ALT activities were significantly increased in tramadol treated groups compared with control group rats. Similarly, Youssef and Zidan, (2016) demonstrated that serum AST and ALT activities were highly significant increase in tramadol treated rats when compared with normal group.

The liver plays a main role in metabolism, and has a number of functions in the body, including glycogen storage, detoxification of most substances, plasma protein synthesis, and production of bile; an alkaline compound which aids in digestion (Gartner and Hiatt, 2000). Furthermore, the liver is known to form some metabolites in the process of metabolizing various substances. The harmful metabolites are then packaged for excretion. This appears to form the basis of the liver damage observed in the present study since a high concentration of the metabolites of tramadol are formed by the liver during their metabolism (Nna et al., 2015).

A non-significant decrease in serum AST and ALT activities were observed in tramadol withdrawal therapeutic dose and overdose groups compared with therapeutic dose and overdose groups. While A significant decrease in serum ALT activities was observed in withdrawal overdose group when compared with overdose group. These results are nearly similar to those recorded by Nna et al., (2015) who reported that serum AST and ALT activities were significantly decreased in tramadol withdrawal groups compared with tramadol treated group rats after 8 weeks of tramadol withdrawal.

Presented findings showed that rats administered tramadol exhibited a significant increase in brain tissue MDA and NO concentrations; while a significant decrease in brain tissue SOD and CAT activities in both tramadol therapeutic and overdose groups when compared with normal control group. These results came in accordance with the recorded data of Elwy and Tab, (2014) who reported that administration of tramadol for 30 days induced significant decrease in hepatic tissue SOD, CAT activities and GSH concentration as compared to control rats. Furthermore, Nafea et al., (2016) demonstrated that abuse of tramadol for one month caused significant elevation in MDA (marker of lipid peroxidation) with reduction in the antioxidant (CAT) activity. Ahmed and Kurkar, (2014) found a similar finding in testicular tissue as they reported that tramadol increased the testicular levels of $\mathrm{NO}$ and lipid peroxidation and decreased the enzymatic anti-oxidant activities significantly compared with the control group; as well as immunohistochemical examinations showed that tramadol increased the expression of endothelial nitric oxide synthase in testicular tissues. They concluded that tramadol administration affects the testicular function of adult male rats, and these effects might be through the overproduction of nitric oxide and oxidative stress induced by this drug.

SOD is a fundamental part of the cellular antioxidant defense system (Ghalehkandi, 2015). It is the first defense line against oxidative stress with dismutation of superoxide anion radicals to $\mathrm{H}_{2} \mathrm{O}_{2}$ (Asadpour et al., 2013). Catalase is a haemeprotein in all aerobic cells that metabolize $\mathrm{H}_{2} \mathrm{O}_{2}$ to oxygen and water. These antioxidant enzymes are inactivated by lipid peroxides or ROS. Lipid peroxidation has been used as an indirect marker of oxidant-induced cell injury, when liver is damaged by some chemical toxin; hepatocytes generate a large number of free radicals, causing lipid peroxidation of the cytomembrane to produce MDA. Malondialdehyde levels indirectly reflect the extent of cellular damage by free radicals and are widely used as an index of free radical mediated lipid peroxidation (Mansour, 2000).

The oxidative stress induced by tramadol in the brain was reported by Lemarie 
and Grimm, (2009); Mohamed et al., (2013). They explained this by those complexes I, III, and IV of electron transfer chain in mitochondria were found to be inhibited by tramadol at high doses. Inhibition of complex III resulted in the generation of ROS as a consequence of the intrinsic characteristics of the electron transfer process to this complex from reduced ubiquinone. The brain is particularly susceptible to oxidative damage due to its high levels of oxygen consumption, increased levels of polyunsaturated fatty acid and relatively low levels of enzymatic antioxidants (Butterfield et al., 2002). Chronic administration of tramadol to mice resulted in oxidative stress in brain tissues; and this effect was associated with a significant decrease in brain non-enzymatic antioxidant, intracellular reduced glutathione level and in enzymatic antioxidant, glutathione peroxidase activity (Abdel-Zaher et al., 2011).

Tramadol withdrawal of therapeutic dose and overdose in male rats causes a nonsignificant decrease in serum NO and MDA concentrations while a significant decrease in serum MDA concentration was observed in tramadol withdrawal overdose when compared with overdose group. These results may be similar to those recorded by Elwy and Tab, (2014) who reported that after 30 days of stopping tramadol causes returned back of hepatic tissue MDA concentration to normal value. Also, Nafea et al., (2016) suggested that 30 days of tramadol withdrawal in male rats causes a significant decrease in brain tissue MDA concentrations. Oxidative stress induced by tramadol on different organs by induction of inflammatory reaction that is effectively reduced after withdrawal period was explained by (Popovic et al., 2009).

The obtained results revealed that a significant increase in brain tissue DNA fragmentation and $8-\mathrm{OHdG}$ concentrations in tramadol therapeutic and overdose groups associated with non-significant increase in DNA fragmentation concentration in overdose group compared with the normal control group. These results may be nearly similarly with the recorded data of Ghoneim et al., (2014) who reported that, the apoptotic index was increased in brain and testicular tissues of rats under tramadol administration than the control group.

Oxidative stress-related genes are differentially expressed following chronic morphine administration in a rat model in a study done by Bajic et al., (2012) and they recorded in their study that chronic opioid administration may be involved in oxidative stress which differs according to the age. Apoptosis or programmed cell death is an active process of normal cell death during development and also, occurs as a result of the cytotoxic effect of various neurotoxins. Previous in vitro studies, indicated that exposure to opioid receptor agonists increases their liability to death by apoptotic mechanisms (Sharifipour et al., 2014).

Tramadol withdrawal of therapeutic dose and overdose in male rats causes a significant decrease in brain tissue 8 -OHdG concentration and non-significant decrease in DNA concentrations when compared with therapeutic dose and overdose groups. These results may be similar to those of Ghoneim et al., (2014) who reported that, the apoptotic index was decreased in brain and testicular tissues of rats under tramadol withdrawal for 4 weeks when compared with tramadol treated group. They recorded that most of the histological findings were subsided as there was return of brain tissues towards normal morphology as evidenced by reduced cellularity and decreased perineuronal haloes as well as normal blood vessels. Multiple pyramidal cells and granular cells appeared normal; however, few pyramidal cells are shrunken and surrounded by haloes. This indicates that the apoptosis activity as well as the oxidative stress damage of brain tissue mostly lowered in this tramadol withdrawal group. These results are in agreement with those of Khodeary et al., (2010). They recorded that whereas rats examined after the withdrawal recovery period unlikely showed complete recovery (did not return back to normal control) but marked reduction in cellular damage was observed when compared to tramadol treated groups.

Presented findings showed that rats administered tramadol exhibited a significant increase in brain tissue caspase-3 concentrations in tramadol overdose group associated with a non-significant increase in the therapeutic dose group when compared with the normal control group. These results came in accordance with those of Nafea et al., (2016) who reported that, abuse of tramadol for one month induced neurotoxicity which proved behaviorally, biochemically and 
increase in the apoptotic marker caspase-3 expression. Abuse of tramadol during adolescence caused behavior alteration in the form of impaired spatial memory and antidepressant-like effect. Also, he recorded that, elevation of caspase- 3 in brain tissue was indicators that abuse of tramadol had the potential to induce oxidative stress. Caspase-3 activity is early detected in apoptosis, continues to increase as cells undergo apoptosis, and rapidly declines in late stages of apoptosis (Schwerk and Schulze-Osthoff, 2003). Ghoneim et al., (2014) reported that tramadol-induced brain histopathological alterations were similar to the results of a study conducted tramadol caused cortical layers disorganization, hypercellularity and increased apoptotic cells.

A significant decrease in brain tissue caspase-3 concentrations was observed in tramadol withdrawal overdose group compared with overdose group while there was a non-significant decrease in caspase-3 concentrations in tramadol withdrawal therapeutic group when compared with the therapeutic group. These results may be similar to those of Nafea et al., (2016) who reported that, following 30 days of tramadol withdrawal the antidepressant-like behaviour was reversed, more improvement in antioxidants and apoptotic markers ( caspase3 ) was evident, as well as incomplete recovery of brain histopathological alteration. The partial recovery of brain tissue after tramadol withdrawal could be supported by Maschke et al., (1999) who stated that gradual improvement of heroin-induced toxic leukoencephalopathy was observed after 4 weeks of heroin exposure and nearly complete recovery was noticed after 6 months of exposure (Iversen, 2003).

\section{Conclusion:}

The present study demonstrated that tramadol administration induced liver dysfunction, brain injury and oxidative stress in rats as well as degenerating endogenous antioxidant defense system mechanisms. Tramadol exposure produced significant increase in serum AST and ALT and brain tissue MDA, NO, DNA-fragmentation, OHdG and Caspase- 3 . While, markedly decreased in brain tissue SOD and CAT both at the recommended dosage and the high dosage ranges. These findings are of importance to be considered in the patients who use tramadol as a pain killer, especially in the long term conditions.

\section{REFERENCES}

Abdel-Zaher, AO., Abdel-Rahman, MS., ELwasei, FM., 2011. Protective effect of Nigella sativa oil against tramadol-induced tolerance and dependence in mice: Role of nitric oxide and oxidative stress. Neuro Toxicology 32, 725-733.

Ahmed, MA., Kurkar, A., 2014. Effects of opioid (tramadol) treatment on testicular functions in adult male rats: The role of nitric oxide and oxidative stress. Clin Exp Pharmacol Physiol 41, 317-323.

Asadpour, R., Azari, M., Hejazi, M., Tayefi, H. Zaboli, N., 2013. Protective effects of garlic aquous extract (Allium sativum), vitamin $\mathrm{E}$, and $\mathrm{N}$ acetylcysteine on reproductive quality of male rats exposed to lead. Vet Res Forum 4, 251-257.

Atici, S., Cinel, I., Cinel, L., Doruk, N., Eskandari, G., Oral, U., 2005. Liver and kidney toxicity in chronic use of opioids: An experimental long term treatment model. J. Biosci 30(2), 245-252.

Bajic, D., Berde, CB., Commons, KG., 2012. Periaqueductal gray neuroplasticity following chronic morphine varies with age: role of oxidative stress. Neuroscience 226, 165-177.

Bekjarovski, N., Chaparoska, D., and Radulovikj-Bekjarovska, S., 2012. Seizures after use and abuse of tramadol. Prilozi 33, 313-318.

Bloms-Funke, P., Dremencov, E., Cremers, TIFH., Tzschentke, TM., 2011. Tramadol increases extracellular levels of serotonin and noradrenaline as measured by in vivo microdialysis in the ventral hippocampus of freelymoving rats. Neurosci Lett 490(3), 191-195. 
Butterfield, DA., Castegna, A. Lauderback, CM., Drake, J., 2002. Evidence that amyloid beta-peptide-induced lipid peroxidation and its sequelae in Alzheimer's disease brain contribute to neuronal death. Neurobiol Aging $23,655-664$.

Drugs and Therapy Bulletin., 2002. Ultracet 16 (5), 3, Shands at the University of Florida, pp.1-4.

El-Gaafarawi II., 2006. Biochemical Toxicity Induced By Tramadol AdministrationIn Male Rats. Egyptian J Hosp Med 23, 353-362.

Elwy, AM., Tabl, G., 2014. Effects of Chronic Usage of Tramadol, Acetaminophen and Tramacet on Some Biochemical and Immunological Changes in Male Rats. J Drug Res Egypt 35(1), 63-71.

Gartner, LP., Hiatt, JL., 2000. Color Atlas of Histology. Philadelphia: Lippincott Williams \& Wilkins.

Ghalehkandi, GJ., 2015. Garlic (Allium sativum) juice protects from semen oxidative stress in male rats exposed to chromium chloride. Anim Reprod $11,526-532$.

Ghoneim, FM., Khalaf, HA., Elsamanoudy, AZ., Helaly, AN., 2014. Effect of chronic usage of tramadol on motor cerebral cortex and testicular tissues of adult male albino rats and the effect of its withdrawal: histological, immunohistochemical and biochemical study. Int J Clin Exp Pathol 7(11), 7323-7341.

Hafez, EM., Issa, SY., Abdel Rahman, SM., 2015. Parenchymatous Toxicity of Tramadol: Histopathological and Biochemical Study. J Alcohol Drug Depend 3, 225.

Ide, S., Minami, M., Ishihara, K., Uhl, GR., Sora, I. Ikeda, K., 2006. Mu opioid receptor-dependent and independent components in effects of tramadol. Neuropharmacology 51(3), 651-658.

Iversen, L., 2003. Cannabis and the brain. Brain 126 (6), 1252-1270.
Kakkar, P., Das, B., Viswanathan, PN., 1984. A modified spectrophotometric assay of superoxide dismutase. Indian $\mathbf{J}$ Biochem Biophys 21, 130-132.

Khodeary, MF., Sharaf, El-Din, AI., El Kholy, SMS., 2010. A histopathological and immunohistochemical study of adult rats'brain after long term exposure to amadol (tramadol hydrochloride). Mansoura J Forensic Med Clin Toxicol 18, 1-24.

Lee, RF., Steinert, S., 2003. Use of the single cell gel electrophoresis/comet assay for detecting DNA damage in aquatic (marine and fresh water) animals. Mutat Res 544, 43-64.

Lemarie, A., Grimm, S., 2009. Mutations in the heme b-binding residue of SDHC inhibit assembly of respiratory chain complex II in mammalian cells. Mitochondrion 9, 254-260.

Laila, AE., 2012. Hepatic DNA Damage and Abnormality in Serum Protein Pattern Due to Long Term Use of Tramadol in Rats. Egyptian J Hosp Med 49, 810- 826.

Liu, H., Liu, Z., 2013. The investigation of tramadol dependence with no history of substance abuse: a cross-sectional survey of spontaneously reported cases in Guangzhou City, China. Biomed Res Int 2013, 283425.

Luck, H., 1974. Estimation of catalase. In: methods in enzymatic analysis. $2^{\text {nd }}$ ed, New York. Bergmeyer. Academic Press Pp. 885-890.

Mansour, MA., 2000. Protective effects of thymoquinone and desferrioxamine against hepatotoxicity of carbon tetrachloride in mice. Life Sci 66(26), 2583-2591.

Maschke, M., Fehlings, T., Kastrup, O., Wilhelm, HW., Leonhardt, G., 1999. Toxic leukoencephalopathy after intravenous consumption of heroin and cocaine with unexpected clinical recovery. J Neurol 246(9), 850-851. 
Mesbah, L., Soraya, B., Narimane, S., Jean, PF., 2004. Protective effect of flavonides against the toxicity of vinblastine cyclophosphamide and paracetamol by inhibition of lipid peroxydation and increase of liver glutathione. Haematol 7 (1), 59-67.

Meyer, R., Patel, AM., Rattana, SK., Quock, TP., Mody, SH., 2014. Prescription opioid abuse: a literature review of the clinical and economic burden in the United States. Popul Health Manag 17(6), 372-387.

Mohamed, TM., Abdel Ghaffar, HM., El Husseiny, RM., 2013. Effects of tramadol, clonazepam, and their combination on brain mitochondrial complexes. Toxicol Ind Health 31(12), 1325-1333.

Moratti, E., Kashanpour, H., Lombardelli, T., Maisto, M., 2010. Intravenous misuse of buprenorphine: characteristics and extent among patients undergoing drug maintenance therapy. Clin Drug Investig 30, 3-11.

Murthy, P., Manjunatha, N., Subodh, BN., Chand, PK., Benegal, V., 2010. Substance use and addiction research in India. Indian J Psychiatry 52 (Suppl 1), S189-99.

Nafea, OE., ElKhishin, IA., Awad, OA., Mohamed, DA., 2016. A study of the neurotoxic effects of tramadol and cannabis in adolescent male albino rats. Int J Sci Rep 2(7), 143-154.

National Institute on Drug Abuse (NIDA) [Cited On: 2014]. The Science of Drug Use and Addiction: The Basics. Available from: https://www.drugabuse.gov/publicati ons/media-guide/science-drug-abuseaddiction-basics. [Accessed On: 23 Oct., 2016].

Nna, VU., Akpan, UP., Okon, VE., Atangwho, IJ., 2015. Hepatotoxicity following separate administration of two phosphodiesterase-5 inhibitors (sildenafil \& tadalafil) and opioid (tramadol); evaluation of possible reversal following their withdrawal. J Appl Pharm Sci 5(08), 105-113.

Pantelias, K., Grapsa, E., 2011. Drug abuse and kidney. Hippokratia 15, 4-8.

Popovic,M., Janicijevic-Hudomal, S., Kaurinovic, B., Rasic, J., Trivic, S., Vojnović, M., 2009. Antioxidant effects of some drugs on immobilization stress combined with cold restraint stress. Molecules 14, 4505-4516.

Raffa, RB., Friderichs, E., Reimann, W., Shank, RP., Codd, EE., Vaught, JL., 1992. Opioid and nonopioid components independently contribute to the mechanism of action of tramadol, an 'atypical' opioid analgesic. J Pharmacol Exp Ther 260(1), 275-285.

Sharifipour, M., Izadpanah, E., Nikkhoo, B., Zare, S., Abdolmaleki, A., Hassanzadeh, K., Moradi, F., Hassanzadeh, K., 2014. new pharmacological role for donepezil: attenuation of morphine-induced tolerance and apoptosis in rat central nervous system. J Biomed Sci 23, 21-6.

Schumann, G., Bonora, R., Ceriotti, F., Férard, G., Ferrero, CA., Franck, PF., Gella, FJ., Hoelzel, W., Jørgensen, PJ., Kanno, T., Kessner, A., Klauke, R., Kristiansen, N., Lessinger, JM., Linsinger, TP., Misaki, H., Panteghini, M., Pauwels, J., Schiele, F., Schimmel, HG., Weidemann, G., Siekmann, L., 2002. IFCC primary reference procedures for the measurement of catalytic activity concentrations of enzymes at 37 degrees C. International Federation of Clinical Chemistry and Laboratory Medicine. Part 6. Reference procedure for the measurement of catalytic concentration of gammaglutamyltransferase. Clin Chem Lab Med 40(7), 734-738. 
Schwerk, C., Schulze-Osthoff, K., 2003. Nonapoptotic functions of caspases in cellular proliferation and differentiation. Biochem Pharmacol 66(8), 1453-1458.

Shi, B., De-Girolami, U., He, J., Wang, S., Lorenzo, A., Busciglio, J., Gabuzda, D., 1996. Apoptosis induced by HIV-1 infection of the central nervous system. J Clin Invest 98, 1979-1990.

United Nations Office on Drugs. and Crime (UNODC), 2014. World Drug Report. United Nations publication, Report No: 12.XI.1 .

Valko, M., Leibfritz, D., Moncol, J., Cronin, MT., Mazur, M., Telser, J., 2007. Free radicals and antioxidants in normal physiological functions and human disease. Int $\mathrm{J}$ Biochem Cell Biol 39(1), 44-84.

Vodovotz, Y., 1996. Modified microassay for serum nitrite and nitrate. BioTechniques 20, 390-394.

Wu, WN., McKown, LA., Gauthier, AD., Jones, WJ., Raffa RB., 2001. Metabolism of analgesic, tramadol hydrochloride, in rat and dog. Xenobiotica 31(7), 423-441.

Youssef, SH., Zidan, AHM., 2016. Histopathological and Biochemical Effects of Acute and Chronic Tramadol Drug Toxicity on Liver, Kidney and Testicular Function in Adult Male Albino Rats. J Med toxicol clin forensic med 1, 2-7. 